\title{
The Impact of SNSs Usage on Social Capital and Knowledge Sharing in Organization
}

\author{
A. Prasetio ${ }^{1,2}$, A. P. Prasetio ${ }^{2}$ \\ ${ }^{1}$ Program Doktor Ilmu Manajemen \\ Universitas Pendidikan Indonesia \\ ${ }^{2}$ Fakultas Ekonomi \& Bisnis, Universitas Telkom \\ Bandung, INDONESIA \\ adhipras@gmail,.com
}

\section{R. Hurriyati}

Program Doktor Ilmu Manajemen

Universitas Pendidikan Indonesia Bandung, INDONESIA

\author{
R. Ferinia \\ Fakultas Ekonomi \\ Universitas Advent Indonesia \\ Bandung, INDONESIA
}

\section{Christin}

Program Doktor Fakultas Ilmu Komunikasi

Universitas Padjadjaran

Bandung, INDONESIA

\begin{abstract}
Organizational learning is affected by knowledge sharing. This paper seeks to add to the research on the role of social capital in promoting knowledge sharing among employees in Social Networking Sites. We examined the influence of SNSs usage on social capital that has 3 dimensions: structural (social interaction ties), relational social capital (trust, norms of reciprocity, and identification), cognitive (shared vision) and then social capital's influence on knowledge sharing among 97 employees. The result was analyzed using PLS-SEM method to examine the hypotheses. The results showed that Social Networking Sites usage affects Social Capital and cognitive dimension of social capital influence knowledge sharing.
\end{abstract}

Keywords- knowledge sharing; social capital; social networking sites;

\section{INTRODUCTION}

An organization will experience profit by building an effective network of relationships with key stakeholders [1]. For example, Marketing is not a single department responsibility, but a company-wide activities [2]. Another example is that customers now can contribute and work together with production department employees to develop a new product in an activity called co-production [3]. Therefore, It is important to facilitate organizational learning and knowledge sharing among employees, departments within organization and external partners to develop organizational capabilities [4].

One of important aspect to develop organizational capabilities is organizational learning. Organizational learning is a social phenomenon during which individual beliefs and assumptions are combined with those of others to create shared systems of meaning for the group members [5]. This Organizational learning process is also affected by knowledge sharing [6].

Physical environment is an important factor in the creation, sharing, and maintenance of organizational knowledge [5]. Online environment especially in social network sites has the same social characteristic with physical environment since computer and internet can facilitate organization to connect each other easily. This kind of internet service called Web 2.0, a technology that allow it's user to interact actively each other like daily social life [7], offers business organizations to enhance knowledge management system to interact with customers and partners [8].

Social media is one of Web 2.0's most popular services. This service lies in a social network sites (SNSs) [9]. Kaplan and Haenlein defined social media as "a group of Internetbased applications that build on the ideological and technological foundations of Web 2.0, and that allow the creation and exchange of User Generated Content" [10]. Web 2.0 enables businesses to complement existing company capabilities by integrating multiple Web 2.0 platforms include knowledge management initiatives, project management efforts, and social networks that connect employees in various activities [8].

It's important to understand how knowledge is shared in SNSs through social capital [11] to enhance organizational learning within organization. This understanding will help organizations to leverage their SNSs effectively and at the same time build their social capital, since it generates a positive effect of interaction among employees [12].

Social capital can be measured with three dimensions: structural (the overall pattern of connections between actors), relational (the kind of personal relationships people have developed with each other through a history of interactions), and cognitive (those resources providing shared representation, interpretations, and systems of meaning among parties) [13] [14]. Few studies have examined the relationships between SNSs, social capital, and knowledge sharing. Even though [15] explore the relationship between the use of SNSs, social capital, and knowledge sharing but his research used various kind of respondent, so it's not conclude how these relationship behave among employees.

We believe that all social capital dimensions mentioned by [14] affected by SNSs usage [15] and play an important role in sharing knowledge. Based on former researches, we believe that social interaction ties [13] [16] [15], trust [11] [16], norms of reciprocity [13], identification [11] [13], and shared vision [13] [16] [15] play an important role in sharing knowledge in online social networking environments. 
This paper seeks to add to the research on the role of social capital in promoting knowledge sharing among employees in Social Networking Sites. The research questions are [1] does the use of SNSs build all dimensions of social capital for employee? [2] Do all dimensions of social capital facilitate knowledge sharing in SNSs for employee?

\section{LITERATURE REVIEW}

\section{A. Social Capital}

Intellectual and social capitals, have been identified as two forms of human capital. These constructs are being refined since they are critical for organizational performance and success. Social capital premise believe that social networks have value.

There are many definitions regarding social capital based on their primarily focus. We can categorize their definitions into 3 categories, whether they focus primarily on [1] the relations an actor maintains with other actors (external linkage), [2] the structure of relations among actors within a collectivity (internal linkage), or [3] both types of linkages [17]. Other categorization mentioned by De Lone showed that the components of the organizational enablers construct for social capital are: Bridging or weak ties and bonding or strong ties [18].

Nahapiet and Ghoshal views social capital as the third category of social capital that include both external and internal linkage [17]. Nahapiet \& Ghoshal defined social capital as "the sum of the actual and potential resources embedded within, available through, and derived from the network of relationships possessed by an individual or social unit. Social capital thus comprises both the network and the assets that may be mobilized through that network" [14]. Moreover they suggest that social capital has of three dimensions: structural, relational, and cognitive [14].

\section{B. Social Network Sites and Social Capital}

The definition of Social Network Sites (SNSs) is webbased services that allow individuals to [1] construct a public or semi-public profile within a bounded system, [2] articulate a list of other users with whom they share a connection, and [3] view and traverse their list of connections and those made by others within the system [19].

SNSs allow people to meet strangers and friends through connection called "latent ties" [20]. This latent ties will change into weak ties and strong ties, but usually SNSs will articulate weak ties [21]. There are researches on SNSs that have found out its positive relationship with social capital [22] [23] [24] [15]. Even though those studies found various positive significant relationship between SNSs and social capital, on the other hand, [11] research did not find relationship between SNSs and some relational dimensions construct of social capital (norms and obligations).

Following Nahapiet and Ghoshal, the structural dimension of social capital is manifested as social interaction ties, the relational dimension is manifested as trust, norm of reciprocity and identification, and the cognitive dimension is manifested as shared vision and shared language [14]. We exclude shared language since it has no significant relationship with SNSs usage [13].

Based on those, we hypothesize the following:

H1a: The SNS usage intensity increases user's perceived Social Interaction Ties in SNSs

H1b: The SNS usage intensity increases user's perceived Trust in SNSs

H1c: The SNS usage intensity increases user's perceived Norm of Reciprocity in SNSs

H1d: The SNS usage intensity increases user's perceived Identification in SNSs

H1e: The SNS usage intensity increases user's perceived Shared Vision in SNSs

\section{Social Capital and Knowledge Sharing}

Knowledge defined as "information processed by individuals including ideas, facts, expertise, and judgments relevant for individual, team, and organizational performance" [25]. Moreover, Wang \& Noe defined knowledge sharing as "the provision of task information and know-how to help others and to collaborate with others to solve problems, develop new ideas, or implement policies or procedures" [25].

Researches that studied relationship between social capital and knowledge sharing showed various result. Social interaction ties showed to have positive significant relationship with knowledge sharing [13] [16] [15] but no relationship in [26]. Other research found that Trust has significant positive relationship with knowledge sharing [16], but has no significant relationship with knowledge sharing as showed in [11] [13] [15]. Norms of reciprocity found to have significant relationship with knowledge sharing (13), but no significant relationship in [15].

Identification found to have significant positive relationship with knowledge sharing [13] but no relationship in [11] [15]. Shared vision found to have negative significant relationship with knowledge quality [13] [16] but has no relationship in [26]. Accordingly, we hypothesize the following:

H2a: user's perceived Social Interaction Ties increases knowledge sharing in SNSs.

H2b: user's perceived Trust increases knowledge sharing in SNSs.

H2c: user's perceived Norm of Reciprocity increases knowledge sharing in SNSs.

H2d: user's perceived Identification increases knowledge sharing in SNSs.

H2e: user's perceived Shared Vision decreases knowledge sharing in SNSs.

Object of this research is to study proportion between SNSs intensity and user's social capital and proportion between user's social capital and their knowledge sharing especially among employee. 


\section{MethodOLOGY}

The survey was conducted online to examine the intensity of use of SNSs relationship with users' relational social capital, and knowledge sharing. We use Partial Least Squares Path Modeling (PLSPM) or PLS-SEM to examine the hypotheses since this method is the suitable for theory development and prediction [27]. Hair, et.al also mentioned that PLS-SEM can be used for an exploratory or an extension of an existing structural theory, such as this research.

\section{A. Measurement Development}

[14] and [13] use this sub dimension to manifest the 3 dimensions of social capital: the structural dimension of social capital manifested as social interaction ties, the relational dimension manifested as trust, norm of reciprocity and identification, and the cognitive dimension manifested as shared vision. This research used those sub dimensions as reference.

The initial items on the all dimensions were based on [15]. All of those items were examined through an online questionnaire to found out their reliability and validity. Reliability was tested by using Cronbach's Alpha and validity using corrected items correlation.

\section{B. Survey Administration}

Facebook is the most popular SNSs in Indonesia, so we assume that Facebook users are representative for SNSs in Indonesia. The survey was offered online through Facebook, web sites, and twitter during November 2013 - June 2014. Respondents was asked first if they are a Facebook user or not to filter only Facebook users respondent. To increase response rate, we offer gift like e-book and top up for their cellular phone. Sample responses received from 97 respondents. The descriptive statistic shows that 84 of respondents are males and 11 females.

\section{RESULT}

PLS-SEM is suitable if the sample size is relatively low [27] between 30-100 samples [28]. The rule of thumb for calculating sample size is that "PLS-SEM minimum sample size should be equal to the larger of the following: (1) ten times the largest number of formative indicators used to measure one construct or (2) ten times the largest number of structural paths directed at a particular latent construct in the structural model" [27]. Using that criteria, the minimum sample size for this research is 70, referring to the number of indicator for SNSs (7 indicators).

[27] mentioned several rule of thumbs for Reflective Measurement Models as follows: Composite reliability should be higher than 0.70 , Indicator loadings should be higher than 0.70 , the average variance extracted (AVE) should be higher than 0.50, the AVE of each latent construct should higher than the construct's highest squared correlation with any other latent construct, and an indicator's loadings should be higher than all of its cross loadings. The data meet all those criteria after omitting the first question for SNS usage about how frequent they access SNSs.
The results of the hypothesis summarized in table I. The results show that hypothesizes $\mathrm{H} 1 \mathrm{a}, \mathrm{H} 1 \mathrm{~b}, \mathrm{H} 1 \mathrm{c}, \mathrm{H} 1 \mathrm{~d}, \mathrm{H} 1 \mathrm{~d}$, and H1e are supported. H2e result is significant, but Shared Vision is not proved negatively related to Knowledge Sharing. Shared Vision is positively related to knowledge sharing.

The survey was conducted online to examine the intensity of use of SNSs relationship with users' relational social capital, and knowledge sharing. We use Partial Least Squares Path

TABLE I. HYPOTHESIS SUMMARIES RESULT

\begin{tabular}{|l|l|l|}
\hline \multicolumn{1}{|c|}{ Hypothesis } & Supported & \multicolumn{1}{c|}{ t-statistics } \\
\hline SNSs $\rightarrow$ SIT & Yes & $\mathbf{1 0 . 1 3 9}$ \\
\hline SNSs $\rightarrow$ Trust & Yes & $\mathbf{3 . 1 2 4}$ \\
\hline SNSs $\rightarrow$ NoR & Yes & $\mathbf{4 . 2 1 9}$ \\
\hline SNSs $\rightarrow$ Identification & Yes & $\mathbf{5 . 9 1 8}$ \\
\hline SNSs $\rightarrow$ SV & Yes & $\mathbf{5 . 3 9 3}$ \\
\hline SIT $\rightarrow$ KS & No & 0.876 \\
\hline Trust $\rightarrow$ KS & No & 0.521 \\
\hline NoR $\rightarrow$ KS & No & 0.462 \\
\hline Identification $\rightarrow$ KS & No & 1.098 \\
\hline SV $\rightarrow$ KS & Yes & $\mathbf{4 . 4 3 8}$ \\
\hline
\end{tabular}

The R2 value shown in table II shows that SIT, Identification and $\mathrm{KS}$ can be explained by the model. R2 values of $0.75,0.50$, or 0.25 for endogenous latent variables in the structural model can be described as substantial, moderate, or weak, respectively [27]. The R2 values show that $\mathrm{KS}$ is explained the most $(\mathrm{R} 2=.658)$, SIT the second most $(\mathrm{R} 2=$ $.392)$, and Identification the third most $(\mathrm{R} 2=.288)$.

TABLE II. R2 VALUE

\begin{tabular}{|l|l|}
\hline \multicolumn{1}{|c|}{ Endogenous } & \multicolumn{1}{c|}{$\mathbf{R}^{\mathbf{2}}$} \\
\hline SIT & 0.3921 \\
\hline Trust & 0.1048 \\
\hline NoR & 0.1848 \\
\hline Identification & 0.2881 \\
\hline SV & 0.2135 \\
\hline KS & 0.6578 \\
\hline
\end{tabular}

\section{DISCUSSION}

As predicted, SNS usage intensity increases all social capital dimensions among employees. The results also show that shared value are positively related to knowledge sharing, but there is no significant relationship between SIT, trust, norm of reciprocity and identification with knowledge sharing.

The results showed that for employee in organization all social capital dimensions are relevant to SNSs use. This findings are consistent with [11] [22] [23] [24] results about the relationship between SNSs usage and social capital more specifically relationship dimension. Additionally, this study support [15] that there are relationships between SNSs usage with structural dimension and between SNSs usage with cognitive dimension of social capital. This could be caused by the nature of SNSs users' reason to use SNSs. The amount of SNSs usage usually reflects a users' interest to use SNSs in order to achieve their goals through their network, like gaining and maintaining social capital dimensions. 
This research found that social interaction ties has no significant effect on knowledge sharing. For employee, the structural dimension doesn't have significant effect. Employee will be likely to share knowledge not based on their network structure. As long as they think it's necessary, they will share knowledge in their SNSs.

These findings also consistent with [11] that found no relationship between relational dimensions of social capital with knowledge sharing. Trust, Norm of Reciprocation and Identification are already existed among employees. This could be the explanation why all relational dimensions have no significant effect on knowledge sharing.

The next finding is that there is a significant positive relationship between cognitive dimension with knowledge sharing in SNSs among employees which is inconsistent with [15] and [13] findings, that showed significant relationship. The cognitive dimension means that people are willing to share their knowledge when they think that the other have the same vision to share their knowledge as well. Even though the majority of SNSs are organized primarily organized based on people, not on interests [11], but for closely related users like among employee, this will result in sharing common interest.

\section{IMPLICATIONS}

The result of this study showed that there are positive relationship between SNS and some social capital dimensions. This study found that shared vision has positive relationship with knowledge sharing. This finding indicates that social networking environments offer an opportunity for employee in organizations to interact each other. An organization could facilitate use of SNSs amongst its employees, so that it could use SNSs as a tool to promote social interaction ties, trust, and identification norm of reciprocity and shared vision among employees. Finally, employees could use SNSs for knowledge sharing to solve various problems.

\section{CONCLUSIONS}

This research showed that the relationship between SNSs and social capital exists. We can conclude that the relationship between SNSs and Social Capital is positive among employee users. The result also showed that there is positive relationship between cognitive dimension of social capital and knowledge sharing among employee respondents.

However, there are some limitations in this study. First, this study focuses on SNS use in employee from various backgrounds with no specific industry. Future research should try to use employees from specific industry backgrounds. Second, this study focuses on Facebook users. Future research should consider using other SNS users. Third, this study only focuses on social capital as predictor for knowledge sharing. Future study could consider studying other factors that could affect knowledge sharing in SNS.

\section{REFERENCES}

[1] Homburg C, Workman JP, Harley K. Marketing's Influence within the Firm. Journal of Marketing. 1999 January; 63: p. 1-15.
[2] Kotler P, Keller KL. Marketing Management 14th Edition New Jersey: Prentice Hall; 2012.

[3] Bowen DE, Jones GR. Transaction Cost Analysis of Service Organization-Customer Exchange. The Academy of Management Review. 1986 April; 11(2): p. 428-441.

[4] Lengnick-Hall ML, Lengnick-Hall CA. Human Resource Management in the Knowledge Economy-New Challenges-New Capabilities San Fransisco: Berret-Koehler; 2003.

[5] McGrath R, Sparks W. Knowledge, Social Capital and Organizational Learning: The Impact of the Physical Environment on Innovation. International Journal of Management. 2005/2006; 5(9): p. 125-129.

[6] Swift PE, Hwang A. The Impact of Affective and Cognitive Trust on Knowledge Sharing and Organizational Learning. The Learning Organization. 2013; 20(1): p. 20-37.

[7] Evans D. Social Media Marketing: The Next Generation of Business Engagement Indianapolis: Wiley Publishing; 2010.

[8] Lee I. Overview of emerging web 2.0-based business models and web 2.0 applications in businesses: An ecological perspective. International Journal of E-Business Research. 2011; 7(4): p. 1-16.

[9] Chu SC, Kim Y. Determinants of consumer engagement in electronic word-of-mouth (eWOM) in social networking site. International Journal of Advertising. 2011; 30(1): p. 47-75.

[10] Kaplan AM, Haenlein M. Users of the world, unite! The challenges and Opportunities of Social Media. Business Horizons. 2010; 53(1): p. 5968.

[11] Choi JH, Scott JE. Electronic Word of Mouth and Knowledge Sharing on Social Network Sites: A Social Capital Perspective. Journal of Theoritical and Applied Electronic Commerce Research. 2013 April; 8(1): p. 69-82.

[12] Putnam RD. Bowling Alone: The Collapse and Revival of American Community New York: Simon \& Schuster; 2000.

[13] Chiu CM, Hsu MH, Wang ETG. Understanding Knowledge Sharing in Virtual Communities: An Integration of Social Capital and Social Cognitive Theories. Decision Support Systems. 2006; 42(3): p. 18721888 .

[14] Nahapiet J, Ghoshal S. Social Capital, Intellectual Capital and the Organizational Advantage. Academy of Management Review. 1998; 23(2): p. 242-268.

[15] Prasetio A. Understanding Knowledge Sharing and Social Capital in Social Network Sites. International Journal of Science and Research (IJSR). 2014 March; 3(3): p. 760-766.

[16] Tsai W, Ghoshal S. Social Capital and Value Creation: The Role of Intrafirm Networks. The Academy of Management Journal. 1998 August; 41(4): p. 464-476.

[17] Adler PS, Kwon SW. Social Capital: Prospects for a New Concept. The Academy of Management Review. 2002 January; 27(1): p. 17-40.

[18] DeLone W, Espinosa JA, Carmel E. Bridging global boundaries for IS roject success. In Proceedings of the 38th Hawaii International Conference on System Sciences; 2005; Honolulu. p. 1-10.

[19] Boyd DM, Ellison NB. Social network sites: Definition, history, and scholarship. Journal of Computer-Mediated Communication. 2008; 13(1): p. 210-230.

[20] Haythornthwaite C. Social networks and Internet connectivity effects. Information, Communication, and Society. 2005; 8(2): p. 125-147.

[21] Constant D, Sproull L, Kiesler S. The kindness of strangers: The usefulness of electronic weak ties for technical advice. Organization Science. 1996; 7(2): p. 119-135.

[22] Wellman B, Haase AQ, Witte J, Hampton K. Does the Internet increase, decrease, or supplement social capital? Social networks, participation, and community, commitment. American Behavioral Scientist. 2001; 45(3): p. 436-445.

[23] Ellison N, Steinfield C, Lampe C. The benefits of Facebook "friends": Exploring the relationship between college students' use of online social networks and social capital. Journal of Computer-Mediated Communication. 2007; 12(3): p. 1143-1168.

[24] Valenzuela S, Park N, Kee KF. Is There Social Capital in Social Network Site?: Facebook Use and College Student's Life Satisfaction, 
Trust, and Participation. Journal of Computer-Mediated Communication. 2009; 14(4): p. 875-901.

[25] Wang S, Noe RA. Knowledge sharing: A review and directions for future research. Human Resource Management Review. 2010; 20: p. 115-131.

[26] Kakanhalli A, Tan BCY, Wei KK. Contributing knowledge to electronic knowledge repositories: An empirical investigation. MIS Quarterly. 2005; 29(1): p. 113-143.

[27] Hair JF, Ringle CM, Sarstedt M. PLS-SEM: Indeed a Silver Bullet. Journal of Marketing Theory and Practice. 2011; 19(2): p. 139-151.

[28] Ghozali I. SEM Metode Alternatif PLS Semarang: BP-Undip; 2008.

[29] Croasdell D, McLeod A, Simkin MG. Why don't more women major in information systems? Information Technology \& People. 2011; 24(2): p. 158-183.

[30] Yamin S, Kurniawan H. Generasi Baru Mengolah Data Penelitian dengan Partial Least Square Path Modeling Jakarta: Salemba Infotek; 2011.

[31] Wang JS. Trust and relationship commitment between direct selling distributors and customers. African Journal of Business Management. 2009 December; 3(12): p. 862-870. 